\title{
MASDEVALLIA LUERORUM (ORCHIDACEAE: PLEUROTHALLIDINAE), A NEW SPECIES FROM COSTA RICA
}

\author{
Diego Bogarín ${ }^{1,2,4}$, Lizbeth Oses ${ }^{1} \&$ Christina M. Smith ${ }^{3}$ \\ ${ }^{1}$ Jardín Botánico Lankester, Universidad de Costa Rica, P. O. Box 302-7050 Cartago, Costa Rica \\ ${ }^{2}$ Herbario UCH, Universidad Autónoma de Chiriquí, David, Panamá \\ ${ }^{3}$ Dept. of Plant and Microbial Biology, University of Minnesota, St. Paul, MN 55108, U.S.A. \\ ${ }^{4}$ Author for correspondence: diego.bogarin@ucr.ac.cr
}

\begin{abstract}
Masdevallia luerorum from the southern Pacific region of Costa Rica is described and illustrated. It resembles $M$. lata, but differs in the single flowered inflorescence, the shorter sepals, the broad and cylindrical sepaline tube, the smaller mentum beneath the column-foot, a smaller secondary mentum, a slight deflection between the two mentums, and the lip with marginal folds near the middle, apically rounded and conspicuously verrucose. Initial phylogenetic evidence indicated that Masdevallia nicaraguae is closely allied to M. luerorum. However, M. nicaraguae is distinguished by the white flowers suffused with fuchsia stripes toward the bases of sepals and the thick and triangular, shorter sepaline tails of the lateral sepals. Moreover, both species are isolated geographically.
\end{abstract}

Resumen. Se describe e ilustra Masdevallia luerorum del Pacífico sur de Costa Rica. Es similar a M. lata, pero difiere en la infloresencia uniflora, los sépalos más cortos, el tubo sepalino amplio y cilíndrico un mentón más pequeño debajo del pie de la columna, un mentón secundario más corto, una ligera deflexión entre ambos mentones, y el labelo con pliegues marginales cerca de la mitad y apicalmente redondeado y conspicuamente verrucoso. Evidencia filogenética inicial indicó que Masdevallia nicaraguae está estrechamente relacionada con $M$. luerorum. Sin embargo, M. nicaraguae se distingue por las flores blancas con rayas fucsia hacia las bases de los sépalos y colas sepalinas triangulares, más cortas y gruesas. Además, ambas especies están aisladas geográficamente.

KeY wORDs: Epidendreae, Flora of Costa Rica, Masdevallia lata, Masdevallia luerorum, taxonomy

Introduction. Masdevallia Ruiz \& Pav. is one of the most species-rich genera of subtribe Pleurothallidinae with an estimated of 600 species (Dasltröm \& Ruiz Pérez 2015, WCSP 2017). The genus ranges from southern Mexico, Central America and northern Andes to Peru, Bolivia and southern Brazil. The highest concentration of species is found in Colombia (152 spp.), Ecuador (269 spp.) and Peru (197 spp.) (OrtizValdivieso et al. 2016, WCSP 2017). About 42 species are found in Central America, mostly in Costa Rica and Panama. Costa Rica harbors 34 species and 12 of them are endemic (Luer 2003a, Smith et al. 2015, Oses Salas \& Karremans 2016).

Luer (2003a) revised the genus for Costa Rica and clarified most of the taxonomic problems. However, some specimens collected for a taxonomic reassessment of the genus in Costa Rica still cannot be assigned to any known species so far. Recently, Smith et al. (2015) and Oses Salas \& Karremans (2016) added M. jorge-warneri (C.M.Sm., Bogarín \& Pupulin) Bogarín and M. utriculata Luer respectively. However, other collections remained under study until a further understanding of the natural variation of populations allow us to distinguish among them. One of these unclassified collections correspond to a species of Masdevallia, which is restricted to the middle elevations of the southern Pacific region of Costa Rica, morphologically similar to Masdevallia floribunda Lindl., M. lata Rchb.f. and M. ostaurina Luer \& V.N.M. Rao. Here, we describe and illustrate this new species of Masdevallia s.l. following the broad circumscription of the genus (Luer 1986, 2000a, 


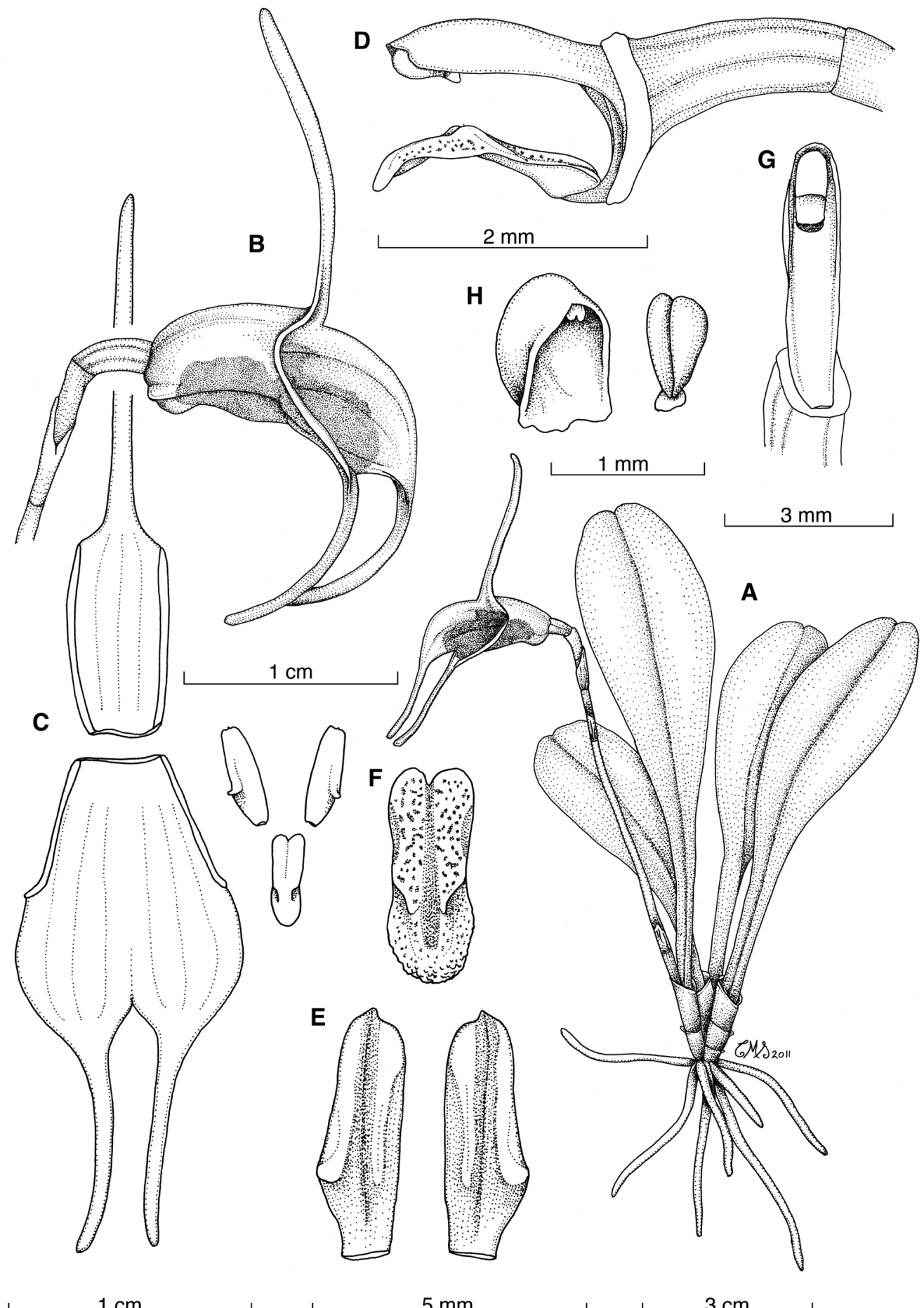

Figure 1. Masdevallia luerorum Bogarín, Oses \& C.M.Sm. A. Habit. B. Flower. C. Dissected perianth. D. Ovary, column and lip, lateral view. E. Petals. F. Lip, adaxial view. G. Column, adaxial view. H. Anther cap and pollinarium. Drawing by C. M. Smith from the holotype (CR). 
2000b, 2001, 2002, 2003a, 2003b, 2006, Dasltröm \& Ruiz Pérez 2015, Vieira-Uribe \& Bogarín 2016).

\section{TAXONOMIC TREATMENT}

Masdevallia luerorum Bogarín, Oses \& C.M.Sm., sp. nov.

TYPE: Costa Rica. San José: Pérez Zeledón, Pejibaye, $9^{\circ} 10^{\prime} 00^{\prime} \mathrm{N} 83^{\circ} 35^{\prime} 00^{\prime} \mathrm{W}, 500 \mathrm{~m}$, premontane wet forest, collected by J. Cambronero, flowered in cultivation in Palmares de San Isidro de Pérez Zeledón, 28 July 2009, D. Bogarin 7364 (holotype, CR; isotypes, JBL, USJ). Figs. 1, 2, 3, 6B.

Species Masdevalliae latae Rchb.f. similis, sed inflorescentia uniflora, sepalibus brevioribus, tubo sepalino latoque cylindrico, mento infra pedem columnae parviore, mento secondario minore, deflectione inter mentos non profunda, plicis marginalibus partem medianam labelli approximates, apice labelli rotundoque conspicue verrucoso differt.

Epiphytic, caespitose, erect herb, up to $9 \mathrm{~cm}$ tall. Roots white, glabrous, flexuous, to $1 \mathrm{~mm}$ in diameter. Ramicauls almost indistinguishable, erect, up to $11 \mathrm{~mm}$ long, $1.5 \mathrm{~mm}$ wide, enclosed by $2-3$ ribbed, tubular sheaths to $10 \mathrm{~mm}$ long. Leaves bright green, erect to suberect, coriaceous, obelliptic, obtuse, emarginate, with a short apiculus, $6-8 \mathrm{~cm}$ long including the petiole, $1-2 \mathrm{~cm}$ wide, the base gradually narrowed into the petiole ca. $1.5 \mathrm{~cm}$ long. Inflorescence apparently single flowered. Peduncle few spotted with brown, suberect, $4.5-7.0 \mathrm{~cm}$ long, with three tubular bracts, one near the pedicel and the other two below the middle. Floral bract tubular, $6 \mathrm{~mm}$ long. Pedicel $10 \mathrm{~mm}$ long. Ovary light green, 3-5 mm long, with 6 straight ribs. Flowers with yellow sepals, suffused with reddish-purple in the lamina of the lateral sepals, petals white, lip white dotted with purple and dark yellow at the apex, column white; the flowers do not produce perceptible fragrances. Dorsal sepal oblong, 22-30 mm long including the tail, $4 \mathrm{~mm}$ wide, connate to the lateral sepals for about $8-10 \mathrm{~mm}$ forming a cylindrical sepaline tube, the free portion about 15 $20 \mathrm{~mm}$ long including the tail, basally subtriangular, abruptly contracted into a slender, erect, apical tail to $13-20 \mathrm{~mm}$ long. Lateral sepals obovate, oblique, 20-30 mm long including the tails, 9-15 mm wide

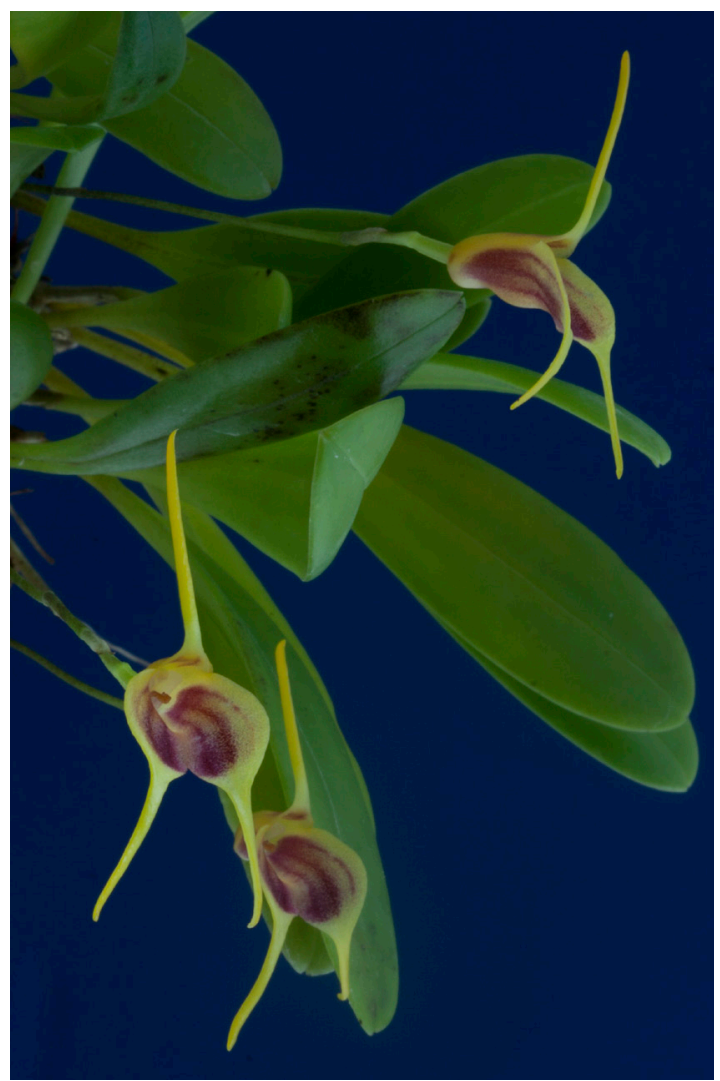

Figure 2. Masdevallia luerorum, from the plant that served as the type specimen, D. Bogarin 7364. Photograph by C.M. Smith.

expanded together, connate for about $6-10 \mathrm{~mm}$ to form a lamina, the free portion about $23-25 \mathrm{~mm}$ long, each basally subtriangular, gradually contracted into a slender, descending, apical tail to $8.5-13.5 \mathrm{~mm}$ long. Petals ovate, oblique, unguiculate, $4.5-5 \mathrm{~mm}$ long, 1.5 $\mathrm{mm}$ wide, the apex obtuse with a small apiculus, the labellar margin with a low, longitudinal callus ending in a short, pointed tooth between the iddle and lower third of the petal. Lip oblong, convex, $4 \mathrm{~mm}$ long, 1.5 $\mathrm{mm}$ wide, with marginal folds near the middle, the apex rounded, verrucose, the base subcordate, hinged beneath. Column semiterete, $4 \mathrm{~mm}$ long, $1 \mathrm{~mm}$ wide. Foot $2 \mathrm{~mm}$ long with a short, incurved extension. Pollinia two, ovoid. Anther cap cucullate.

Distribution: Known only from southern Pacific of Costa Rica along the Fila Costeña (Fig. 4).

Habitat: Epiphytic in premontane wet forest at $500 \mathrm{~m}$ of elevation. 


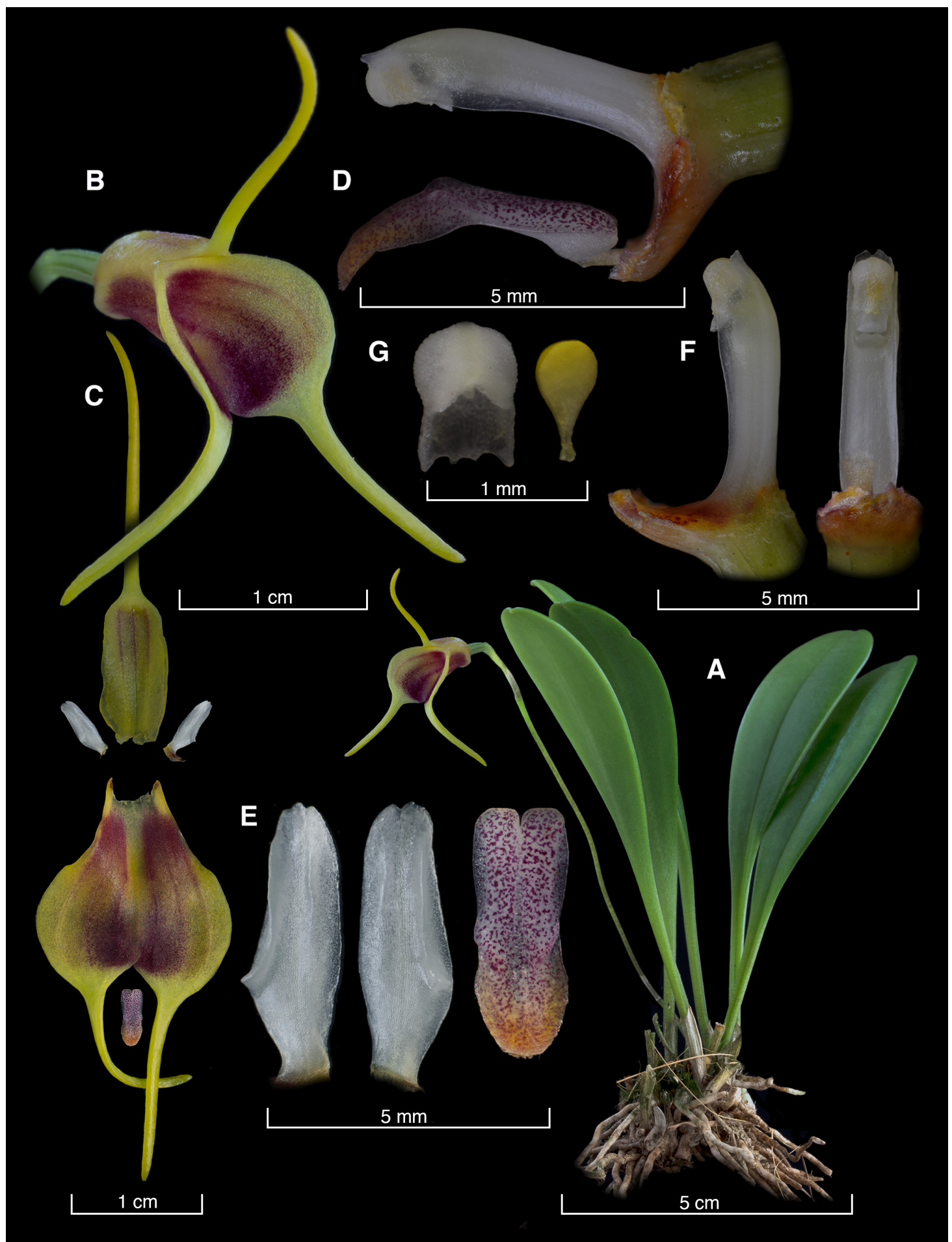

FiguRE 3. Lankester composite dissection plate (LCDP) of Masdevallia luerorum. A. Habit. B. Flower. C. Dissected perianth. D. Column and lip, lateral view. E. Petals and lip, adaxial view. F. Column, lateral and adaxial view. G. Anther cap and pollinarium. Plate by D. Bogarín and L.Oses. Voucher at JBL.

LANKESTERIANA 17(2). 2017. (C) Universidad de Costa Rica, 2017. 
Phenology: Plants bloom in July, September, and October.

Eponymy: Dedicated to Jane and Carlyle A. Luer for their contributions to the taxonomy of Costa Rican Masdevallia.

Masdevallia luerorum can be distinguished from other Costa Rican species by its broad yellow sepals suffused with reddish-purple (Fig. 5). Morphologically, it resembles Masdevallia lata $[=$ Alaticaulia lata (Rchb.f.) Luer] (Fig. 5D, 6). However, the sepals are longer in M. lata than in M. luerorum (dorsal sepal $30 \mathrm{~mm}$ vs. 38-68 mm, lateral sepals $28 \mathrm{~mm}$ vs. 34-65 $\mathrm{mm})$. The color of the sepals is also distinct; there is much more yellow in the lateral sepals of M. luerorum and they are suffused with reddish-purple, while in $M$. lata the sepals are a much darker brownish-red, with yellow restricted to the dorsal sepal and the tails (Luer 2000). The synsepal of M. lata is laterally compressed whereas in $M$. luerorum it forms a cylindrical tube that expands to a more open lamina. Masdevallia luerorum has a small mentum beneath the column foot, a small secondary mentum and between the two mentums a slight deflection, whereas M. lata has a much larger mentum beneath the column foot and a larger secondary mentum and a very conspicuous deflection between the two menta (Luer 2000) (Fig. 5B, 5D). The two species also present differences in the lip. The marginal folds in M. lata are above the middle, whereas in M. luerorum they are below to the

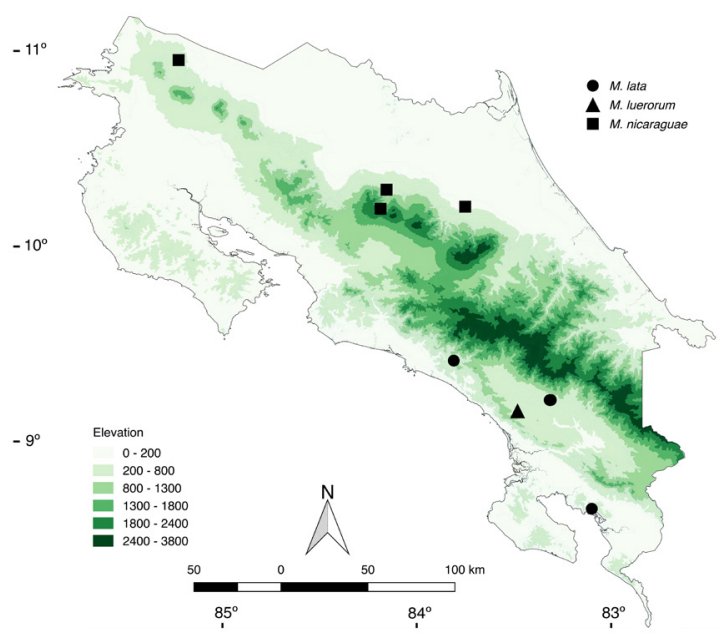

Figure 4. Distribution map of: Masdevallia lata (circles), M. luerorum (triangle) and M. nicaraguae (squares) in Costa Rica.

middle. Furthermore, in M. lata the lip is divided into a well-defined hypochile and epichile, whereas in $M$. luerorum, this division is less evident. The apex of the lip in M. luerorum is rounded and conspicuously verrucose versus an obtuse and minutely verrucose apex in M. lata (Luer 2000).

Both M. lata and M. luerorum are likely sympatric in the vicinity of the Fila Costeña in the southern Pacific of Costa Rica. Masdevallia lata extends from San Isidro de El General towards the south in the Península de Osa and Panama where M. luerorum is
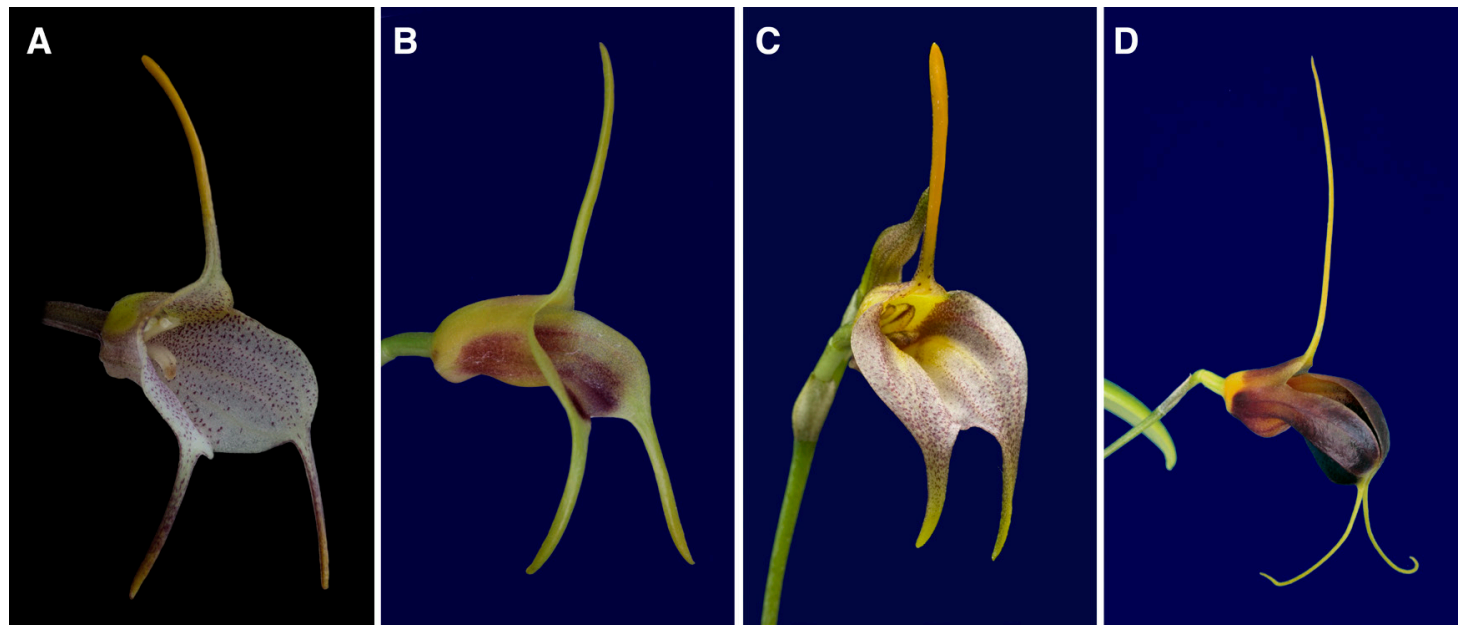

Figure 5. Masdevallia luerorum Bogarín, Oses \& C.M.Sm. and similar morphological species. A. M. floribunda (Bogarín 11335). B. M. luerorum (Bogarín 7364). C. M. ostaurina (Bogarín 5976). D. M. lata (Bogarín 2691). Photographs by D. Bogarín. 


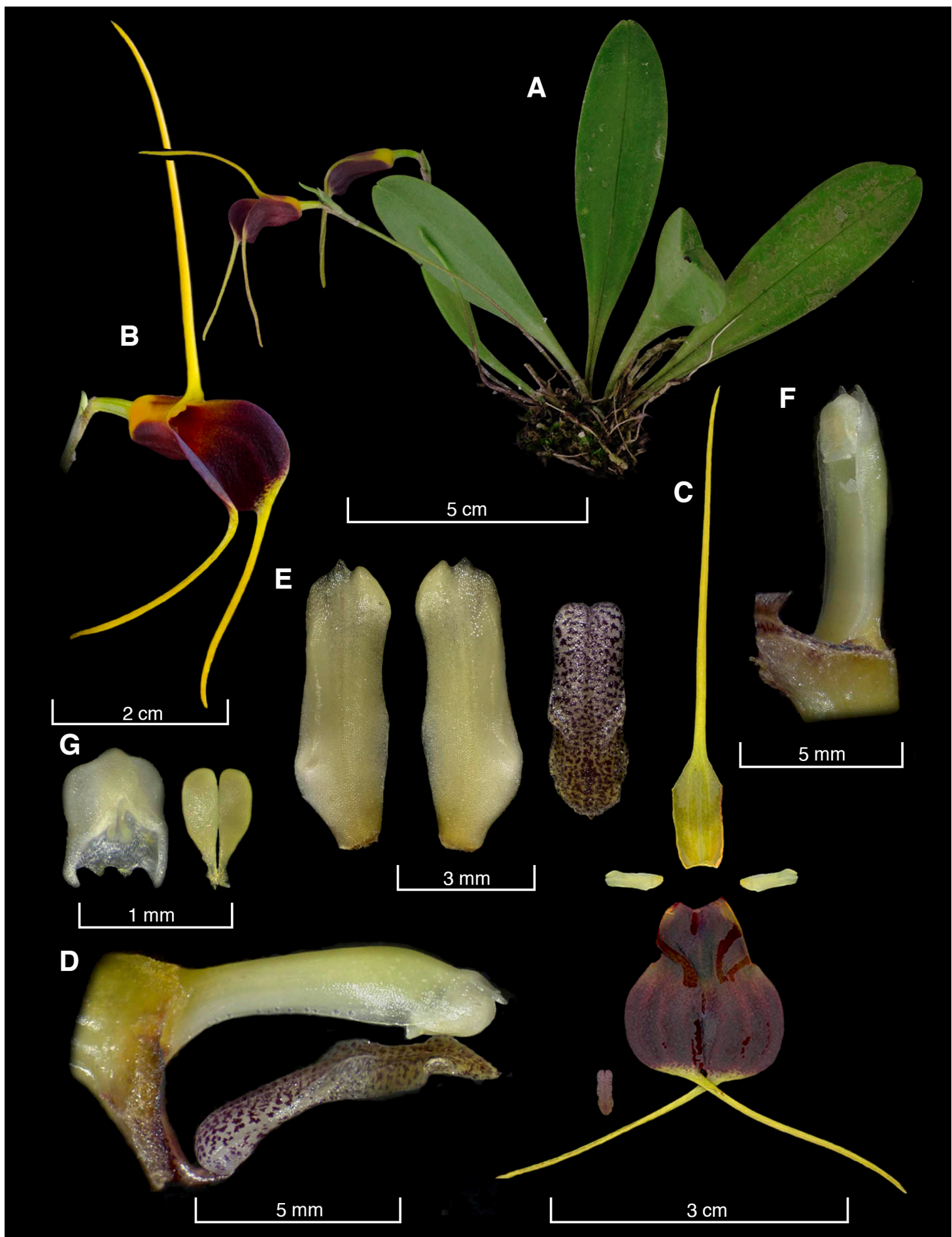

Figure 6. LCDP of Masdevallia lata Rchb.f. A. Habit. B. Flower. C. Dissected perianth. D. Column and lip, lateral view. E. Petals and lip, adaxial view. F. Column, lateral (or $3 / 4$ ) view. G. Pollinarium and anther cap. Plate by D. Bogarín \& C.M. Smith based on Bogarín 11335 (JBL). 
absent. However, both species potentially overlap in the Cordillera Costeña (Fig. 4). The hypothesis that $M$. luerorum might represent a geographical variation of $M$. lata has been initially tested by performing phylogenetic analysis of Bayesian inference (BI) and maximum likelihood (ML) of the nuclear ribosomal internal transcribed spacers (nrITS) and the plastid maturase $\mathrm{K}$ (matK) datasets (Oses et al., in prep.). Both analysis yielded the same topology and suggested that $M$. luerorum and M. nicaraguae Luer are closely related. The species were also grouped with $M$. lata and the Colombian M. pescadoensis Luer \& $\mathrm{R}$. Escobar into a clade with serially branching pattern. Masdevallia lata occupies a basal position (posterior probability for BI reconstruction $=0.94$ ), followed by $M$. pescadoensis (posterior probability $=0.98$ and bootstrap for $\mathrm{ML}=77$ ) whereas $M$. luerorum and $M$. nicaraguae are grouped with strong support (posterior probability=1.0 and bootstrap for $\mathrm{ML}=93$ ).

Masdevallia nicaraguae is distinguished from Masdevallia foribunda Lindl., $M$. luerorum and $M$. lata by the white flowers suffused with rose stripes toward the bases of sepals and the thick, triangular shorter sepaline tails of the lateral sepals (Luer 2003a, Karremans et al. 2012) (Fig. 7). In addition, Masdevallia luerorum and M. nicaraguae are geographically isolated. Masdevallia nicaraguae ranges in the Caribbean lowlands of northern Costa Rica and southern Nicaragua along the San Juan River and the lower slopes of Cordillera de Guanacaste and Tilarán whereas $M$. luerorum is restricted to the Pacific mid-elevation areas of Cordillera Costeña (Fig. 4).

Masdevallia luerorum has little resemblance with Masdevallia floribunda (Figs. 5A, 8) and Masdevallia ostaurina Luer \& V.N.M. Rao (Fig. 5C), but differs in flower coloration; the sepals of M. floribunda and M. ostaurina are white to yellowish or pinkish and dotted with purple to varies degrees and purple-spotted peduncle. Moreover, M. ostaurina has a dark purple lip (vs. lip white dotted with purple) and M. floribunda has a column with a purple margin (vs. without purple margin) (Luer 2001, 2004). Also, Masdevallia floribunda lacks a secondary mentum and has a shorter sepaline tube with a more spreading lamina formed by the lateral sepals (Fig. 8). Furthermore, M. floribunda has a verrucose callus that protrudes both above and beneath lip close to the apex, which is absent in M. luerorum.
Acknowledgments. We thank the Ministerio del Ambiente y Energía of Costa Rica (MINAET) and Sistema Nacional de Áreas de Conservación (SINAC) for issuing the scientific permits. Jorge Cambronero and Gerson Villalobos for collecting and providing the specimens and information. To Mario Blanco, Robert L. Dressler and two anonymous reviewers for their useful suggestions to the manuscript. This study is part of the project: B3080 "Taxonomía y filogenia de Masdevallias del grupo Reichantha (Orchidaceae: Pleurothallidinae) en Costa Rica", supported by Vicerrectoría de Investigación, Universidad de Costa Rica.

\section{Literature Cited}

Dasltröm, S. \& Ruiz Pérez, S. (2015). Two new similar species of Masdevallia (Orchidaceae: Pleurothallidinae) from Pasco, Peru. Lankesteriana, 15(1), 59-65. Doi: http://dx.doi.org/10.15517/lank.v15i1.18524

Karremans, A. P., Bogarín, D., Fernández, M., Smith, C. M. \& Blanco, M. A. (2012). New species and records of Orchidaceae from Costa Rica II. Lankesteriana, 12(1), 19-51. Doi: http://dx.doi.org/10.15517/lank. v12i1.18271

Luer, C. A. (1986). Icones Pleurothallidinarum II. Systematics of Masdevallia (Orchidaceae). Monographs in Systematic Botany from the Missouri Botanical Garden, 16, 1-63.

Luer, C. A. (2000a). Icones Pleurothallidinarum IX. Systematics of Masdevallia part one. Monographs in Systematic Botany from the Missouri Botanical Garden, 77, 1-264.

Luer, C. A. (2000b). Icones Pleurothallidinarum XXI. Systematics of Masdevallia part two. Monographs in Systematic Botany from the Missouri Botanical Garden, 82, 265-518.

Luer, C. A. (2001). Icones Pleurothallidinarum XXII. Systematics of Masdevallia part three. Monographs in Systematic Botany from the Missouri Botanical Garden, 86, 519-780.

Luer, C. A. (2002). Icones Pleurothallidinarum XXIII. Systematics of Masdevallia part four. Monographs in Systematic Botany from the Missouri Botanical Garden, 87, 781-1047.

Luer, C. A. (2003a). Masdevallia. In: Hammel, B. E., Grayum, M. H., Herrera C. \& Zamora, N. (eds.), Manual de plantas de Costa Rica Volumen III: Monocotiledóneas (Orchidaceae-Zingiberaceae) (277291). St. Louis, MO: Missouri Botanical Garden Press.

Luer, C. A. (2003b). Icones Pleurothallidinarum XXV. Systematics of Masdevallia part five. Monographs in Systematic Botany from the Missouri Botanical Garden, 91, 1049-1293.

Luer, C.A. (2004). New genera and combinations in the 


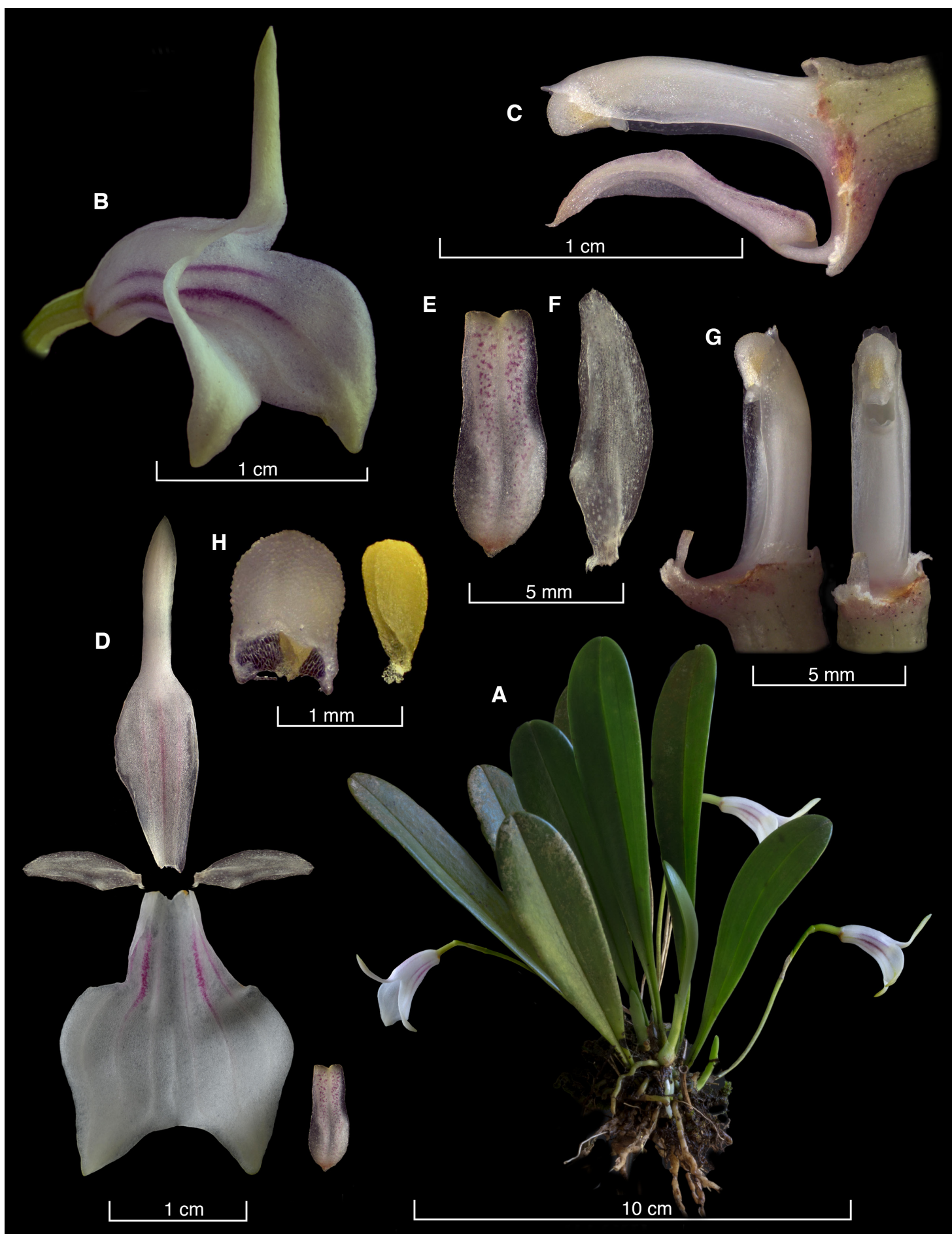

Figure 7. LCDP of Masdevallia nicaraguae Luer. A. Habit. B. Flower. C. Ovary, column and lip, lateral view. D. Dissected perianth. E. Petal. F. Lip, adaxial view. G. Column, adaxial and lateral view. H. Pollinarium and anther cap. Plate by L. Oses based on Karremans 6832 (JBL). 


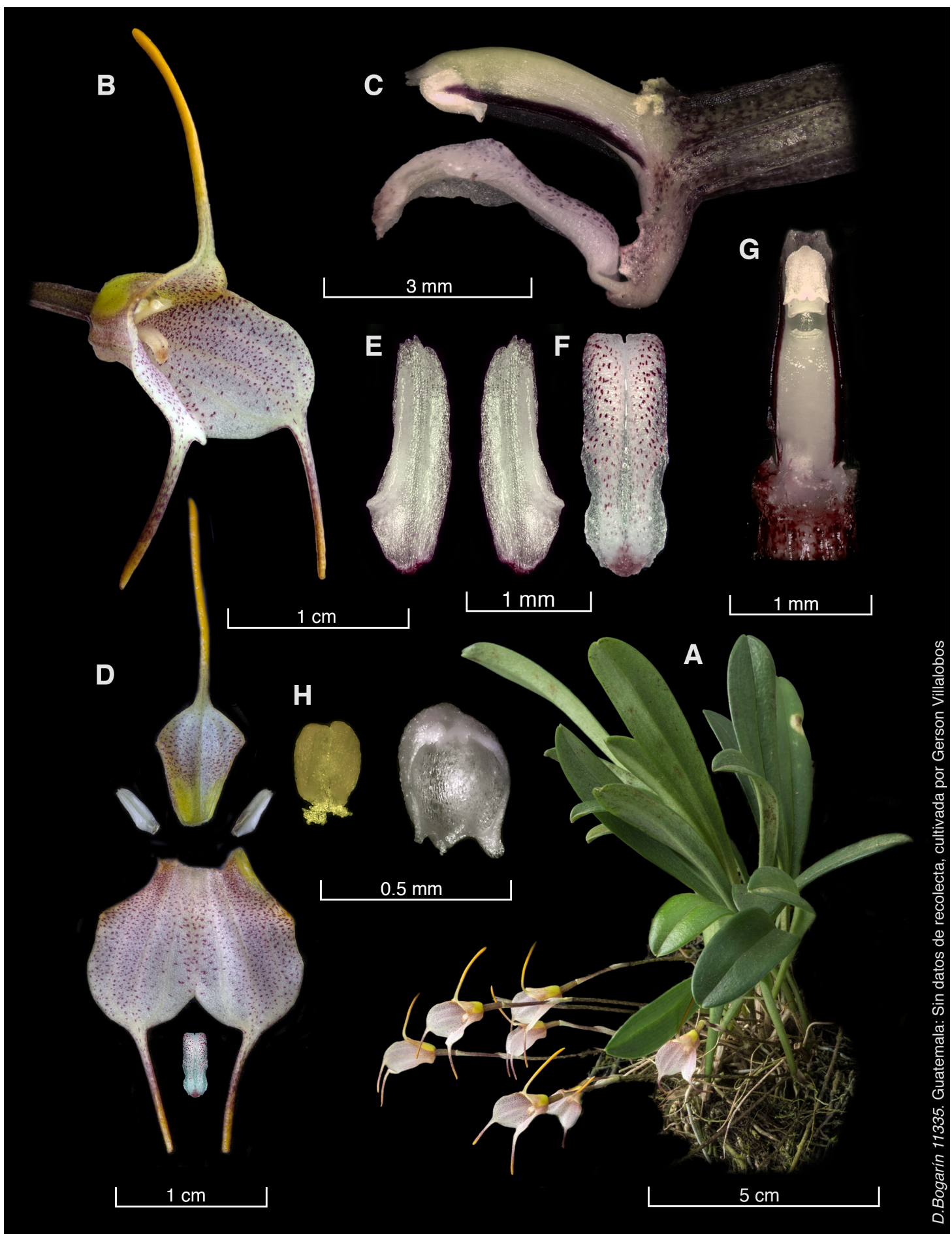

Figure 8. LCDP of Masdevallia floribunda Lindl. A. Habit. B. Flower. C. Ovary, column and lip, lateral view. D. Dissected perianth. E. Petals. F. Lip, adaxial view. G. Column, adaxial view. H. Pollinarium and anther cap. Plate by D. Bogarín based on Bogarin 11335 (JBL). 
Pleurothallidinae. Icones Pleurothallidinarum XXVI. Monographs in Systematic Botany from the Missouri Botanical Garden, 95, 1-265.

Luer, C. A. (2006). Icones Pleurothallidinarum XXVIII. Reconsideration of Masdevallia and the systematics of Specklinia and vegetatively similar taxa. Monographs in Systematic Botany from the Missouri Botanical Garden, 105, 1-300.

Ortiz-Valdivieso, P., Viveros, P., Luer, C. A., Celis, M., Hágsater, E., Blanco, M., Dueñas, H. C., Gerlach, G., van der Berg, C., Carnevali Fernández-Concha, G., Giraldo, G., Bogarín, D., Oakeley, H. F., Romero-González, G., Leopardi-Verde, C. L., Noguera-Savelli, E., Cetzal, W., Bernal, R., Smidt, E. C., Peraza L. N. \& Balam-Narváez, R. (2016). Orchidaceae. In: Bernal, R., Gradstein S. R. \& Celis M. (Eds.). Catálogo de plantas y líquenes de Colombia. (1727-2026). Bogotá: Instituto de Ciencias
Naturales, Universidad Nacional de Colombia.

Oses Salas, L. \& Karremans, A. P. (2016). A note on Masdevallia zahlbruckneri and M. utriculata (Orchidaceae). Harvard Papers in Botany, 21(2), 325336.

Smith, C. M., Bogarín, D. \& Pupulin, F. (2015). A new Reichantha (Orchidaceae: Pleurothallidinae) from Nicaragua and Costa Rica. Systematic Botany, 40(1), 83-87.

Vieira-Uribe, S. \& D. Bogarín. (2016). Una hermosa nueva especie de Masdevallia (Pleurothallidinae: Orchidaceae) de los Andes centrales de Colombia. Orquideología, XXXIII-1, 14-19.

WCSP (2017). World Checklist of Selected Plant Families. Facilitated by the Royal Botanic Gardens, Kew. Retrieved from http://apps.kew.org/wcsp/ advanced.do 